\title{
Announcements
}

\section{AAMC Annual Meeting}

Join AAMC November 1-6, 2013 in Philadelphia for compelling, critical conversations about the changing landscape of medical education, research, and patient care. For information: www.aamc.org.

\section{The Generalists in Medical Education Conference 2013}

The Annual Generalists in Medical Education conference will be held November 1-2, 2013 at the Hotel LeMéridien in Philadelphia, PA, USA. The theme of the conference is The Development of Professional Identity for the Future of Medicine. For conference details, please visit the website at www.thegeneralists.org/conference.html

\section{NVMO meeting}

Annual meeting of the Netherlands Association for Medical Education (NVMO), November 7-8, 2013, Egmond aan Zee, The Netherlands. See www.nvmo.nl for more information on NVMO.

\section{Webcast Audio Seminar 2014 Winter series}

The topic of the WAS Winter series will be: "Practical Applications of Active Learning". The series of lectures will start January 9, 2014. For more details and dates, see www.iamse.org.

\section{1th Asia Pacific Medical Education Conference (APMEC) 2014}

The aim of the conference is to share our experiences as educators, and learn from experts in medical and healthcare professional education some of the latest ideas, and best practices adopted internationally. The theme is: Optimising Collaboration in Medical Education - Building Bridges, Connecting Minds. Dates: January 15-19, 2014 at the National University of Singapore, Singapore. More details of the conference are available at the website:

medicine.nus.edu.sg/meu/apmec11/

\section{GRIPE Winter Meeting}

The Group for Research In Pathology Education (GRIPE) is an academic society of medical educators who teach pathology. To that end, the group develops and shares teaching resources, promotes scholarly research and innovation in medical education, faculty development materials, and provides mutual support at the annual meeting in January. The meeting 2014 will take place January 16 - 19, 2014 in Galveston, TX, USA at the University of Texas Medical Branch. Meeting website: gripeweb.org

\section{Annual Team-Based Learning Conference}

The Team-Based Learning Collaborative (TBLC) is a group of educators dedicated to supporting faculty from a variety of disciplines that have implemented, or wish to implement, Team-Based Learning. March 6-8, 2014, Fort Worth, TX. For details, see the meeting Website: TBLCMeeting.org

\section{AACOM 2014 Annual Meeting}

The 2014 Annual Meeting will be held April 2-5 2014, Washington DC, at the Capital Hilton Hotel. For more details follow the website:

www.aacom.org/events/annualconf/Pages/An nualConference.aspx

\section{IAMSE 2014 meeting}

The next annual meeting of the International Association of Medical Science Educators (IAMSE) will take place in Nashville, TN, USA. Conference dates are June 7-10, 2014. Deadline for poster abstracts will be January 17, 2014. Please see for more information the meeting website www.iamseconference.org

\section{Individual Journal Subscriptions Available}

Medical Science Educator is accessible for IAMSE members. If you are not a member, you can obtain an individual subscription. Visit this link to apply: www.medicalscienceeducator.org/subscription. $\underline{\mathrm{html}}$ 